\title{
Comparison of techniques for detecting antigens of Giardia lamblia and Cryptosporidium paroum in faeces
}

\author{
G H Tee, A H Moody, A Hunt Cooke, P L Chiodini
}

\begin{abstract}
Aim-To compare the use of commercial monoclonal antibody test systems-the Giardia CEL IF test and the Crypto CEL IF test-for the detection of Giardia lamblia and Cryptosporidium parvum antigens in faeces with conventional techniques.

Methods-Sensitivity and specificity were evaluated using preparations of cysts of $G$ lamblia and purified oocysts of $C$ parvum. Evaluation of 59 random faecal samples passing through the Department of Clinical Parasitology, Hospital for Tropical Diseases, London, was carried out for both organisms. Results-The fluorescence staining techniques proved more sensitive than other tests routinely used for diagnosis.
\end{abstract}

(F Clin Pathol 1993;46:555-558)

Giardiasis and cryptosporidiosis are two of the most commonly seen protozoal causes of diarrhoea. Outbreaks of diarrhoea have been frequently attributed to these organisms ${ }^{1-10}$ and several methods of detection have been described. ${ }^{11-23}$ But the diagnosis of Giardia lamblia and Cryptosporidium parvum infections remains problematic.

Traditionally, giardiasis has been diagnosed by microscopic detection of cysts or trophozoites in samples. Faecal samples are examined directly or with staining, with or without concentration. G lamblia, however, is often difficult to detect and faecal examinations frequently yield equivocal negative results. At times, symptoms of infection are present but parasites are not detected in the faeces. ${ }^{24}$ In as many as $50 \%$ of infected patients parasites can not be demonstrated by a single faecal examination ${ }^{11}$ and additional examinations are required for diagnosis. This is chiefly due to the extreme variability with which the parasite is excreted in both symptomatic and asymptomatic infections.

Current laboratory diagnosis of Cryptosporidium is generally by means of detection of oocysts in faeces, and occasionally in other specimens. Modified Ziehl-Neelsen staining is the method commonly used by the clinical laboratory. ${ }^{1920}$ Phenol-auramine staining is very reliable and is also widely used. Casemore and colleagues acknowledged that difficulties could be encountered distinguishing Cryptosporidium oocysts from non-cryptosporidial bodies, and concluded that no single staining method was completely effective in detecting Cryptosporidium, ${ }^{17}$ a view shared by others. ${ }^{25}$ Microscopic techniques for detection of these protozoa in faeces can be laborious, insensitive, and prone to error if staff are not fully experienced. Fluorescence tagged monoclonal antibody staining has been reported to be more sensitive when compared with a non-immunofluorescence stain in the detection of Giardia antigen. ${ }^{26}$ Machlauchlin et al reported that monoclonal antibody labelling of the Cryptosporidium oocysts provides a more rapid and accurate method of detecting the organism. ${ }^{21}$

Two commercial monoclonal antibody test systems (Giardia-CEL IF and Crypto-CEL IF; Bradsure Biologicals Ltd, Market Harborough, Leicestershire) utilise direct staining of acetone fixed specimens. The fluorescein labelled mouse monoclonal antibodies bind specifically to cell wall components of $G$ lamblia cysts and $C$ parvum oocysts.

The sensitivity of the Giardia-CEL IF test was evaluated by comparing it with direct microscopic examination of suspensions of faeces and also after the addition of Thomson's stain, ${ }^{27}$ with or without concentration, by the formol-ether concentration technique. ${ }^{16}$ The sensitivity of the CryptoCEL IF test (CCIT) was evaluated by comparing it with conventional staining methods: Giemsa, modified Ziehl-Neelsen (MZN), ${ }^{17}$ and phenol-auramine ${ }^{28}$ using both purified oocysts and faecal samples.

\section{Methods}

Cysts of $G$ lamblia and oocysts of $C$ parvum were obtained from faecal samples submitted for routine parasitological examination at the Department of Clinical Parasitology, Hospital for Tropical Diseases, London. Purified oocysts of $C$ parvum were provided by Dr V McDonald.

\section{DETERMINATION OF THE SENSITIVITY OF} DETECTION OF Giardia Lamblia CYSTS ANTIGENS

Using a faecal sample containing cysts of $G$ lamblia, two standard methods for examination of faeces were used to compare the monoclonal antibody fluorescence method for detection of Giardia cysts (table 1).

A 1 in 10 dilution of unconcentrated faeces in saline was examined using direct examination of the saline suspension, and direct examination of the saline suspension with the addition of Thomson's stain. After formol- 
Table 1 Number of $G$ lamblia cysts in $5 \mu l$ unconcentrated and concentrated faecal sample

\begin{tabular}{lll}
\hline Methods & $\begin{array}{l}\text { Unconcentrated } \\
\text { faeces }\end{array}$ & $\begin{array}{l}\text { Concentrate from } \\
\text { formol-ether } \\
\text { concentration } \\
\text { technique }\end{array}$ \\
\hline $\begin{array}{l}\text { Direct examination of wet preparation } \\
\text { Direct examination of wet preparation with } \\
\text { Thomson's stain }\end{array}$ & 1 & 35 \\
Giardia-CEL IF test & 12 & 35 \\
\hline
\end{tabular}

Table 2 Number of $G$ lamblia cysts in $5 \mu l$ of concentrates from 10 faecal samples

\begin{tabular}{llll}
\hline $\begin{array}{l}\text { Specimen } \\
\text { number }\end{array}$ & $\begin{array}{l}\text { Direct examination } \\
\text { of concentrate }\end{array}$ & $\begin{array}{l}\text { Direct examination } \\
\text { of concentrate } \\
\text { with Thomson's stain }\end{array}$ & $\begin{array}{l}\text { Giardia-CEL } \\
\text { IF test }\end{array}$ \\
\hline 1 & 302 & 526 & 950 \\
2 & 14 & 3 & 200 \\
3 & 14 & 9 & 50 \\
4 & 5 & 5 & 50 \\
5 & 242 & 650 & 600 \\
6 & 599 & 15 & 750 \\
7 & 21 & 14 & 150 \\
8 & 15 & 14 & 100 \\
9 & 24 & 23 & 200 \\
10 & 56 & & \\
\hline
\end{tabular}

ether concentration of the same faecal sample, the deposit was examined using similar laboratory procedures.

Concentrated and unconcentrated faecal suspensions $(5 \mu \mathrm{m})$ were used to prepare smears for the Giardia-CEL IF test. These were air dried and fixed in acetone for $5 \mathrm{~min}$ utes and stained according to the manufacturer's instructions.

Ten faecal samples (1-10) containing cysts of $G$ lamblia were concentrated and $5 \mu \mathrm{l}$ of the deposit was used to prepare smears which were examined in a similar manner (table 2). The total number of cysts present in each coverslip preparation was counted using $\times 400$ magnification. The slides for the Giardia-CEL IF test were examined using $\times 400$ magnification with a Zeiss Axioskop fluorescence microscope.

A further 20 random faecal samples, without prior knowledge of the parasitological findings, were examined in a similar manner, and the presence and absence of cysts noted (table 3).

Table 3 Random examination of unknown faecal samples for cysts of G lamblia

\begin{tabular}{llll}
\hline & \multicolumn{2}{l}{ No of samples positive for $G$ lamblia cysts by: } \\
\cline { 2 - 4 } $\begin{array}{l}\text { Number of } \\
\text { faecal samples }\end{array}$ & $\begin{array}{l}\text { Direct examination } \\
\text { of concentrate }\end{array}$ & $\begin{array}{l}\text { Direct examination of } \\
\text { concentrate with } \\
\text { Thomson's stain }\end{array}$ & $\begin{array}{l}\text { Giardia-CEL } \\
\text { IF test }\end{array}$ \\
\hline 20 & $3 / 20$ & $3 / 20$ & $5 / 20$ \\
\hline
\end{tabular}

Table 4 Number of $C$ parvum oocysts in $5 \mu$ of each faecal dilution by four staining methods

\begin{tabular}{|c|c|c|c|c|}
\hline $\begin{array}{l}\text { Dilutions (No } \\
\text { of oocysts } / \mathrm{ml} \text { ) }\end{array}$ & Giemsa & $\begin{array}{l}\text { Modified } \\
\text { Ziehl- } \\
\text { Neelsen }\end{array}$ & $\begin{array}{l}\text { Phenol- } \\
\text { auramine }\end{array}$ & $\begin{array}{l}\text { Crypto- } \\
\text { CEL IF } \\
\text { test }\end{array}$ \\
\hline $\begin{array}{l}1 \text { in } 100\left(9 \times 10^{5}\right) \\
1 \text { in } 200\left(4.5 \times 10^{5}\right) \\
1 \text { in } 400\left(2.3 \times 10^{5}\right) \\
1 \text { in } 800\left(1.1 \times 10^{5}\right) \\
1 \text { in } 1600\left(5 \times 10^{4}\right) \\
1 \text { in } 3200\left(2.5 \times 10^{4}\right) \\
1 \text { in } 6400\left(1.3 \times 10^{4}\right) \\
1 \text { in } 12800\left(6 \times 10^{3}\right) \\
1 \text { in } 25600\left(3 \times 10^{3}\right)\end{array}$ & $\begin{array}{r}130 \\
30 \\
18 \\
13 \\
0 \\
0 \\
0 \\
0 \\
0\end{array}$ & $\begin{array}{r}605 \\
165 \\
105 \\
25 \\
0 \\
0 \\
0 \\
0 \\
0\end{array}$ & $\begin{array}{r}638 \\
481 \\
207 \\
122 \\
45 \\
22 \\
19 \\
11 \\
4\end{array}$ & $\begin{array}{r}1151 \\
911 \\
502 \\
303 \\
133 \\
50 \\
46 \\
11 \\
6\end{array}$ \\
\hline
\end{tabular}

DETERMINATION OF THE SENSITIVITY OF DETECTION OF PURIFIED $C$ PAFrUm OOCYSTS IN FAECAL SUSPENSION

Three standard methods for staining faeces were used in comparison with the monoclonal antibody fluorescence Crypto-CEL IF test (4) for detection of $C$ parvum oocysts. The stains used were Giemsa (1), modified Ziehl-Neelsen (2), and phenol-auramine stain (3) (table 4).

A suspension $(50 \mu \mathrm{l})$ containing about $9 \times$ $10^{7} / \mathrm{ml}$ of purified $C$ parvum oocysts preserved in potassium dichromate was washed three times in phosphate buffered saline (PBS), $\mathrm{pH}$ $7 \cdot 2$. The pellet of washed oocysts was resuspended in $2.5 \mathrm{ml}$ of PBS. This was mixed with $10 \mathrm{ml}$ of 1 in 10 faecal suspension to make a dilution of 1 in 100 . Further serial dilutions of 1 in 200 to 1 in 25600 were made by doubling dilutions in saline.

Five microlitres of each faecal oocyst dilution were used to make smears which were air dried and fixed in acetone for 5 minutes before staining with methods $1-4$. The total numbers of oocysts in $5 \mu \mathrm{l}$ of each dilution were counted. Smears stained with methods 1-2 were examined at $\times 400$ magnification using a light microscope. Smears stained with methods 3-4 were examined at $\times 400$ magnification using a Zeiss Axioskop fluorescence microscope.

\section{DETERMINATION OF THE SENSITIVITY OF} DETECTION OF $C$ ParvUM OOCYSTS FROM FAECAL SAMPLES

Nine formalised ( $1 \mathrm{~g} / 10 \mathrm{ml} 10 \%$ formalin) faecal samples previously found to contain oocysts of $C$ parvum were homogenised and $5 \mu \mathrm{l}$ was used to prepare smears which were examined using the four stains described before. The total number of oocysts in each $5 \mu \mathrm{l}$ of sample was counted (table 5).

A further 20 random faecal samples, without prior knowledge of the parasitological findings, were examined in a similar manner, and the presence and absence of oocysts noted (table 6).

Five formalised faecal samples previously found to contain oocysts of $C$ parvum were homogenised and concentrated using two concentration methods: (1) standard formolether concentration technique; (2) modified formol-ether concentration method. ${ }^{17}$ Two smears were prepared using $5 \mu \mathrm{l}$ of well mixed deposit, air dried, and fixed in acetone for 5 minutes. Smears were also prepared directly from the homogenised faeces in a similar manner. All smears were stained using modified Ziehl-Neelsen, phenol-auramine, and CCIT and the total number of oocysts present was counted (table 7).

Table 1 shows the results from faecal samples examined for Giardia cysts with and without concentration. From the unconcentrated faecal samples, direct examination of saline suspension with the addition of Thomson's stain detected 12 times more cysts than the suspensions without Thomson's stain. The Giardia-CEL IF test, however, detected three times more cysts 
Table 5 Number of $C$ parvum oocysts in $5 \mu$ l of formalised faecal sample

\begin{tabular}{lcccc}
\hline Specimen number & Giemsa & $\begin{array}{l}\text { Modified } \\
\text { Ziehl-Neelsen }\end{array}$ & Phenol-auramine & $\begin{array}{l}\text { Crypto- } \\
\text { CEL IF test }\end{array}$ \\
\hline 1 & 53 & 63 & 103 & 129 \\
2 & 8 & 15 & 127 & 78 \\
3 & 8 & 4 & 6 & 7 \\
4 & 8 & 10 & 34 & 17 \\
5 & 63 & 198 & 450 & 467 \\
6 & 45 & 80 & 130 & 211 \\
7 & 10 & 28 & 27 & 52 \\
8 & 35 & 213 & 355 & 566 \\
9 & 33 & 60 & 96 & 633 \\
\hline
\end{tabular}

Table 6 Examination of random faecal samples for oocysts of $C$ parvum

\begin{tabular}{lllll}
\hline & \multicolumn{4}{l}{ No of samples positive for C parvum oocysts by: } \\
\cline { 2 - 5 } $\begin{array}{l}\text { Number of } \\
\text { faecal sample }\end{array}$ & Giemsa & $\begin{array}{l}\text { Modified } \\
\text { Ziehl-Neelsen }\end{array}$ & Phenol-auramine & $\begin{array}{l}\text { Crypto- } \\
\text { CEL IF test }\end{array}$ \\
\hline 20 & $1 / 20$ & $1 / 20$ & $3 / 20$ & $4 / 20$ \\
\hline
\end{tabular}

than the saline suspension with Thomson's stain. After concentration, the Giardia-CEL IF test detected almost 10 times more cysts than the other methods.

Table 2 shows that Giardia-CEL IF test has the greatest detection rate showing 10/10 samples with the highest number of cysts detected. The sensitivity of direct examination of concentrate and direct examination of concentrate with the addition of Thomson's stain in comparison with Giardia-CEL IF test was $41 \cdot 0 \%$ and $49 \cdot 2 \%$, respectively.

Table 3 shows Giardia-CEL IF test detected five positives from 20 random faecal samples; by other methods three of 20 were positive. In comparison with Giardia-CEL IF test, the sensitivity of direct examination of concentrates and direct examination of concentrates with the addition of Thomson's stain were both $60 \%$. Table 4 shows that the Giemsa stain was the least sensitive method for the detection of $C$ paroum oocysts. Phenol-auramine and Crypto-CEL IF tests detected oocysts up to a dilution of 1 in 25 600; Giemsa and modified Ziehl-Neelsen could only detect oocysts up to a dilution of 1 in 800. The Crypto-CEL IF test detected twice as many oocysts as phenol-auramine. Except on the first dilution of 1 in 100 , the

Table 7 Comparison of the numbers of $C$ parvum oocysts in $5 \mu l$ samples found by direct faecal examination and concentration techniques

\begin{tabular}{|c|c|c|c|c|}
\hline \multirow[b]{2}{*}{$\begin{array}{l}\text { Specimen } \\
\text { number }\end{array}$} & \multirow[b]{2}{*}{$\begin{array}{l}\text { Laboratory } \\
\text { technique }\end{array}$} & \multicolumn{3}{|c|}{ Staining method } \\
\hline & & $\begin{array}{l}\text { Modified } \\
\text { Ziehl-Neelsen }\end{array}$ & Phenol-auramine & $\begin{array}{l}\text { Crypto- } \\
\text { CEL IF test }\end{array}$ \\
\hline 1 & $\begin{array}{l}\text { DFS } \\
\text { FEC } \\
\text { MFEC }\end{array}$ & $\begin{array}{l}63 \\
33 \\
85\end{array}$ & $\begin{array}{l}103 \\
134 \\
106\end{array}$ & $\begin{array}{l}129 \\
195 \\
147\end{array}$ \\
\hline 2 & $\begin{array}{l}\text { DFS } \\
\text { FEC } \\
\text { MFEC }\end{array}$ & $\begin{array}{l}0 \\
0 \\
5\end{array}$ & $\begin{array}{r}6 \\
16 \\
25\end{array}$ & $\begin{array}{r}7 \\
11 \\
45\end{array}$ \\
\hline 3 & $\begin{array}{l}\text { DFS } \\
\text { FEC } \\
\text { MFEC }\end{array}$ & $\begin{array}{l}80 \\
50 \\
28\end{array}$ & $\begin{array}{l}130 \\
170 \\
232\end{array}$ & $\begin{array}{l}211 \\
440 \\
421\end{array}$ \\
\hline 4 & $\begin{array}{l}\text { DFS } \\
\text { FEC } \\
\text { MFEC }\end{array}$ & $\begin{array}{l}28 \\
38 \\
15\end{array}$ & $\begin{array}{r}27 \\
144 \\
99\end{array}$ & $\begin{array}{r}52 \\
159 \\
78\end{array}$ \\
\hline 5 & $\begin{array}{l}\text { DFS } \\
\text { FEC } \\
\text { MFEC }\end{array}$ & $\begin{array}{r}85 \\
119 \\
383\end{array}$ & $\begin{array}{r}355 \\
890 \\
1332\end{array}$ & $\begin{array}{r}566 \\
1383 \\
1817\end{array}$ \\
\hline
\end{tabular}

Keys: DFS: Direct faecal smear; FEC: Formol-ether concentration, MFEC: Modified formolether concentration.
Crypto-CEL IF test detected five times more oocysts than modified Ziehl-Neelsen and 12 times more oocysts at a dilution of 1 in 800 . The sensitivity of Crypto-CEL IF test over Giemsa staining was very much greater. In the 1 in 100 dilution Crypto-CEL IF test picked up eight times more oocysts than Giemsa. For the other dilutions, the difference was almost 30 times.

Table 5 shows that the two fluorescence methods detected the greatest number of oocysts in each faecal sample. The sensitivity of detection of the number of oocysts for each method in comparison with the Crypto-CEL IF test were $12 \cdot 2 \%$ (Giemsa), $29 \cdot 7 \%$ (modified Ziehl-Neelsen), and $61.5 \%$ (phenolauramine).

Table 6 shows that the Crypto-CEL IF test detected four positives from 20 random faecal samples; by other methods one in 20 (Giemsa, modified Ziehl-Neelsen) and three/20 (phenol-auramine) were positive. The sensitivity of each method in comparison with Crypto-CEL IF test was $25-75 \%$.

Table 7 show the results of examining five direct faecal smears from known $C$ parvum positive faecal samples compared using two concentration methods: (A) standard formolether concentration; (B) modified formolether concentration. After concentration with either methods A or B, the number of oocysts detected by fluorescence staining increased. With modified Ziehl-Neelsen staining, there were lower numbers of oocysts detected even after concentration (specimens 1, 3, and 4), indicating that the various stages of oocyst maturation affect the staining property. From these results, it was shown that concentration of faeces produces a significant increase in numbers of oocysts detected over direct faecal smears when stained by fluorescence methods. This is consistent with findings by other workers. ${ }^{1029}$ No cross-reactivity with the Giardia-CEL IF test was found with cysts of Entamoeba histolytica, Entamoeba coli, Chilomastrix mesnili and Endolimax nana. No cross-reactivity with the Crypto-CEL IF test was found with oocysts of Isospora belli.

\section{Discussion}

It is clear that the Giardia-CEL IF monoclonal fluorescence test for the diagnosis of giardiasis from faecal samples has far greater sensitivity of detection of cysts compared with other conventional methods with or without concentration. The preferred method for diagnosis of cryptosporidiosis is a fluorescence method with the modified ZiehlNeelsen stain as a confirmation (confirming the recommendation of Casemore). ${ }^{17}$ The use of modified Ziehl-Neelsen alone may result in missing oocysts in a light infection.

The performance of the phenol-auramine and CEL-IF test were sufficiently comparable to support the use of either method as a routine procedure, but the higher cost of CryptoCEL IF test kit may limit its role to that of a confirmatory test. 
1 Shaw PK, Brodsky RE, Lyman DO, et al. A community wide outbreak of giardiasis with evidence of transmission by a municipal water supply. Ann Intern Med sion by a municip

2 Moore GT, Cross WM, McGure D, et al. Epidemic Giardiasis at a ski resort. $N$ Engl $₹$ Med 1969;281:402-7.

3 Black RE, Dykes AC, Sinclair SP, Wells JG. Giardiasis in day-care center: evidence of person-to-person transmission. Paediatrics 1977;60:486-91.

4 Keystone JS, Krajden S, Warren MR. Person-to-person transmission of Giardia lamblia in day-care nurseries. Can Med Assoc F 1978;119:241-8.

5 Thacker SB, Simpson S, Gordon JJ, Wolfe N, Kimball AM. Parasitic disease control in a residential facility for the mentally retarded. Am f Public Health 1979;69: the mentall

6 Baxby D, Hart CA, Taylor C. Human cryptosporidiosis: a possible case of hospital cross infection. $\mathrm{Br} \mathrm{Med} \mathcal{F} 1983$ 287:1760-1

7 Koch KL, Philips DJ, Aber RC, Current WL. Cryptosporidiosis in hospital: evidence for person-toperson transmission. Ann Intern Med 1985;102:593-6.

8 Anonymos. Cryptosporidiosis among children attending day care centres, Georgia, Pennyslvania, Michigian, California, New Mexico. MMWR 33:599-601.

9 D'Antonia R, Winn RE, Taylor JP, et al. A waterborne outbreak of cryptosporidiosis in normal hosts. Ann outbreak of cryptosporidio

10 Hayes EB, Matte TD, O’Brien TR, McKinley TW, Logsdon GS, Rose JB. Large community outbreak of cryptosporidiosis due to contamination of a filtered public water supply. $N$ Engl $\mathcal{F}$ Med 1989;320:1372-6.

11 Healy GR. The presence and absence of Giardia lamblia in studies on parasite prevalence in the U.S.A. In: Jakabowski W, Hoff JC, eds. Waterborne transmission of giardiasis. Washington, D.C: US Environmental Protection Agency. 1979;92-101.

12 Green GL, Miles MA, Warhurst DC. Immunodiagnostic detection of Giardia antigen in faeces by a rapid visual enzyme-linked immunosorbent assay. Lancet 1985; 691-3.

13 Craft JC, Nelson JD. Diagnosis of giardiasis by counterimmunoelectrophoresis of faeces. $\mathcal{F}$ Infect Dis 1982;145: 499-504.

14 Visvesvara GS, Smith PD, Healy GR, Brown WR. An immunofluorescence test to detect serum antibodies to Giardia lamblia. Ann Intern Med 1980;93:802-5.
15 Riggs JL, Dupus KW, Nakamura K, Spath DP. Detection of Giardia lamblia by immunofluorescence. Appl Environ Microbiol 1983;45:698-700.

16 Allen AVH, Ridley DS. Further observation on the formol-ether concentration technique for faecal parasites. F Clin Pathol 1970;23:54-6.

17 Casemore DP, Armstrong M, Sands RL. Laboratory diagnosis of cryptosporidiosis. $\mathcal{f}$ Clin Pathol 1985;38 $1337-41$.

18 Arrowood MJ, sterling CR. Comparison of conventional staining methods and monoclonal antibody-based methods for Cryptosporidium oocysts detection. $f$ Clin Microbiol 1989;27:1490-5.

19 Garza D, Hopter R1, Eichelberger C, Eisenbach S Fainstein V. Faecal staining methods for screening Cryptosporidium oocysts. $\mathcal{f}$ Med Technol 1984;1:560-3.

20 Garcia LS, Bruckner DA, Brewer TC, Shimizu RY. Techniques for the recovery and identification of Cryptosporidium oocysts from faecal specimens. $f \mathrm{Clin}$ Microbiol 1983;18:185-90.

21 McLauchlin J, Casemore DP, Harrison TG, et al. Identification of Cryptosporidium oocysts by monoclonal antibody. Lancet 1987; i:51.

22 Garcia LS, Brewer TC, Bruckner DA. Fluorescent detection of Cryptosporidium oocysts in human faecal specimens by using monoclonal antibodies. $¥$ Clin Microbiol mens by using

23 Jokipii L, Pohjla S, Jokipii AMM. Cryptosporidium: A frequent finding in patients with gastrointestinal symptoms. Lancet 1983;i:358-61.

24 Rendtorff RC. The experimental transmission of human intestinal protozoan parasites II. Giardia lamblia cysts given in capsules. Am F Hyg 1954;59:209-20.

25 Ma P, Soave R. Three step faecal examination for cryptosporidiosis in 10 homosexual men with protracted watery diarrhoea. F Infect Dis 1983;147:824-8.

26 Galland $\mathrm{L}$, Bueno $\mathrm{H}$. Advances in laboratory diagnosis of intestinal parasites. Am Clin Lab 1989;18-9.

27 Thomas RG. A simple concentration method for the detection of parasitic ova and cysts in faeces. $f$ Clin detection of parasitic

28 Nichols G, Thom BT. Screening for Cryptosporidium in faecals. Lancet 1984;ii:735.

29 Sheather AL. The detection of intestinal protozoa and minge parasites by floatation technique. $\mathcal{f}$ Comp Pathol Ther 1923;36:266-75. 